\title{
Business incubators and accelerators: a co-citation analysis-based, systematic literature review
}

\author{
J. Piet Hausberg ${ }^{1}$ (D) Sabrina Korreck $^{2}$
}

Published online: 29 January 2018

(C) The Author(s) 2018. This article is an open access publication

\begin{abstract}
A long and rich research tradition exists on the phenomenon of business incubators since this kind of venture support institution first emerged. One can observe an increasing heterogeneity of incubation beyond the traditional mainstream focus on regional development and university-based incubators. In the last decade, in particular the phenomenon of accelerators as a particular form of incubators received increasing research interest. A few literature reviews started summarizing the field, but left some important issues unanswered. This systematic review study contributes to this effort deriving current themes and a research agenda. We find that open innovation and social capital theory increasingly complement the resource-based view as frameworks to understand business incubation. Moreover, the phenomenon of private corporate incubators and accelerators gains traction, both in entrepreneurship theory and practice.
\end{abstract}

Keywords Business incubators · Accelerators · Technology incubators · New technology based firms - Systematic review

JEL Classification $\mathrm{L} 26 \cdot \mathrm{O} 25 \cdot \mathrm{O} 32$

J. Piet Hausberg

piet.hausberg@uni-osnabrueck.de

Sabrina Korreck

Sabrina.Korreck@wiso.uni-hamburg.de

1 School of Business Administration and Economics, Osnabrück University, Rolandstr. 8, 29/206, 49078 Osnabrück, Germany

2 Faculty of Business, Economics and Social Sciences, University of Hamburg, Von-Melle-Park 9, B531, 20146 Hamburg, Germany 


\section{Introduction}

The concept of business incubation experienced a considerable evolution and division into several similar institutions and approaches (Mian et al. 2016). After the first private incubator was established in New York in 1959 (Lewis 2001) and the first public incubator in Philadelphia in 1964 (Campbell and Allen 1987), business incubation diffused slowly during the 1960s and 1970s (Hackett and Dilts 2004). By now, incubators have become an integral part of the modern entrepreneurial ecosystem, supporting the growth of new ventures based on a broad range of measures. In fact, we saw the emergence of so many different forms of entrepreneurship support and even more names for them that the result was a significant degree of confusion regarding the terms incubator and accelerator and their delineation from and relation to connected concepts. A result of the evolution of the incubator industry, the forking of its development paths and experimentation with new incubator business models, is that no universal definition has crystallized and that both practitioners and scholars often use similar concepts synonymously.

While there is a considerable history of research on incubators, literature appears to remain fragmented and incubators have long been studied mostly as a peculiar phenomenon in a variety of closely related research streams, above all urban and economic development and university-industry technology transfer. Only recently, research focusing primarily on the phenomenon of business incubators themselves gained traction. We identified a few recent bibliometric and review studies regarding the field of business incubation in general (Albort-Morant and Ribeiro-Soriano 2016; Hackett and Dilts 2004; Mian et al. 2016; Phan et al. 2005) and one such study regarding university incubators in particular (McAdam et al. 2006). Each provides some important insights into and overviews of the topic, but at the same time leaves some equally important questions unaddressed. Probably the first review of the literature on business incubation is that of Campbell and Allen (1987). At the time, the phenomenon of incubators was very recent and hence the research field only embryonic. Consequently, there was little need for the review to be very systematic; it still succeeded to provide an in-depth summary of the very few books and articles available.

Most recently, Albort-Morant and Ribeiro-Soriano (2016) carried out a bibliometric analysis and provide us with insights on the most productive authors, the development of the number of publications over time, the geographical distribution of research in the field, the journals with the most publications and received citations, as well as the type and area of research. However, while undoubtedly useful, bibliometric analyses and their metrics can-if not supplemented by an in-depth review-provide only a first glance at the status quo of the field. Hence, we learn little about theoretical frameworks used or new concepts introduced. Mian et al. (2016), introducing to their special issue on business incubation, provided the most recent literature review. They show a growing interest in the topic and point to the phenomenon of accelerators as a newly emerging, relevant phenomenon for which only very limited research exists.

A more comprehensive study is the systematic literature review by Hackett and Dilts (2004) in this journal. In their careful review, they provide a very good overview of the development of the field in terms of the incubator definitions and configurations, the key findings regarding incubation process and impact, and the challenges that the literature stream faced at the time. However, this review dates back over a decade and we clearly witness the emergence of new empirical phenomena and theoretical developments.

This overview of extant review studies shows that reviews either are at least a dozen years old or are limited to bibliometric analyses. Therefore, our systematic literature 
review aims at pursuing four distinct goals. First, we seek to show the recently consolidating research field regarding business incubators in the network of the most relevant adjacent fields and topics. Second, we intend to derive a most reconcilable definition of the concept of business incubators. Third, we aim at summarizing the state-of-the-art research. Fourth and finally, we pursue the overall goal to conclude the implied persistent research gaps in order to suggest a research agenda.

In the following section, we describe our research design before we present the results of our bibliometric analyses in the subsequent section. After that, the main part of the review covers definitions and typologies of incubators, their processes, as well as research on their performance and impact. From this, we derive research gaps before we conclude with an outlook on future research.

\section{Research design}

In our study, we carried out a systematic literature review that provides a bibliometric and co-citation analysis, similar to the review of entrepreneurship research in general carried out by Schildt et al. (2006). Before we started the actual systematic review, we scanned and read some of the most salient articles in the field in order to determine the search term. Then we used the ISI Web of Science (WoS) database to find all literature on the topic that could be of interest. When using the 'topic' field to search the database, ISI-WoS returns all articles with the search terms in their title, keywords, or abstracts. Scholars in management science consider this database the most comprehensive and use it frequently in systematic reviews (Albort-Morant and Ribeiro-Soriano 2016; Dahlander and Gann 2010; Mian et al. 2016). However, although the ISI-WoS database is one of the most comprehensive scientific journal databases, it is not exhaustive. The sample could therefore miss some important contributions. Moreover, we decided to focus on the most high-ranking journals (see Fig. 1). This also means that the initial sample for the co-citation analysis does not include books, although some provide relevant contributions. However, most of these are included later because relevant papers cite most of the relevant papers and books initially not included and hence they appear at least once in our sample.

Our broad search term was as follows: < "incubat*" OR "business accelerat*" OR "technology accelerat*" OR "company builder*" OR "technology cent*" OR "innovation cent*" $>$. We included the terms company builder and technology/innovation center, because we wanted to reduce the probability to miss relevant literature due to a too limited search. We used the asterisks in order to retrieve results for similar versions and alterations of the terms, like incubation and incubators. We decided not to search for "accelerat*" without business or technology, because this search turned out to deliver a huge number of false positives even in the most pertinent journals, for example, when high-dynamic business environments are investigated and a factor "accelerates" business processes.

We combined the search terms with the constraint that it has to appear in one of the following WoS-categories: management, business, economics, operations research, management science, or urban studies. By this restriction, we could exclude more than 240,000 items from other disciplines such as health care, engineering, or physics. Based on this initial macro-filter, the WoS database returned 601 results. In the second step, we screened the journals for which the search returned at least one article and restricted the search to the journals that could contain relevant articles, which led to a sample comprising 353 articles. In the third step, we screened all returned articles of journals that were not amongst the 


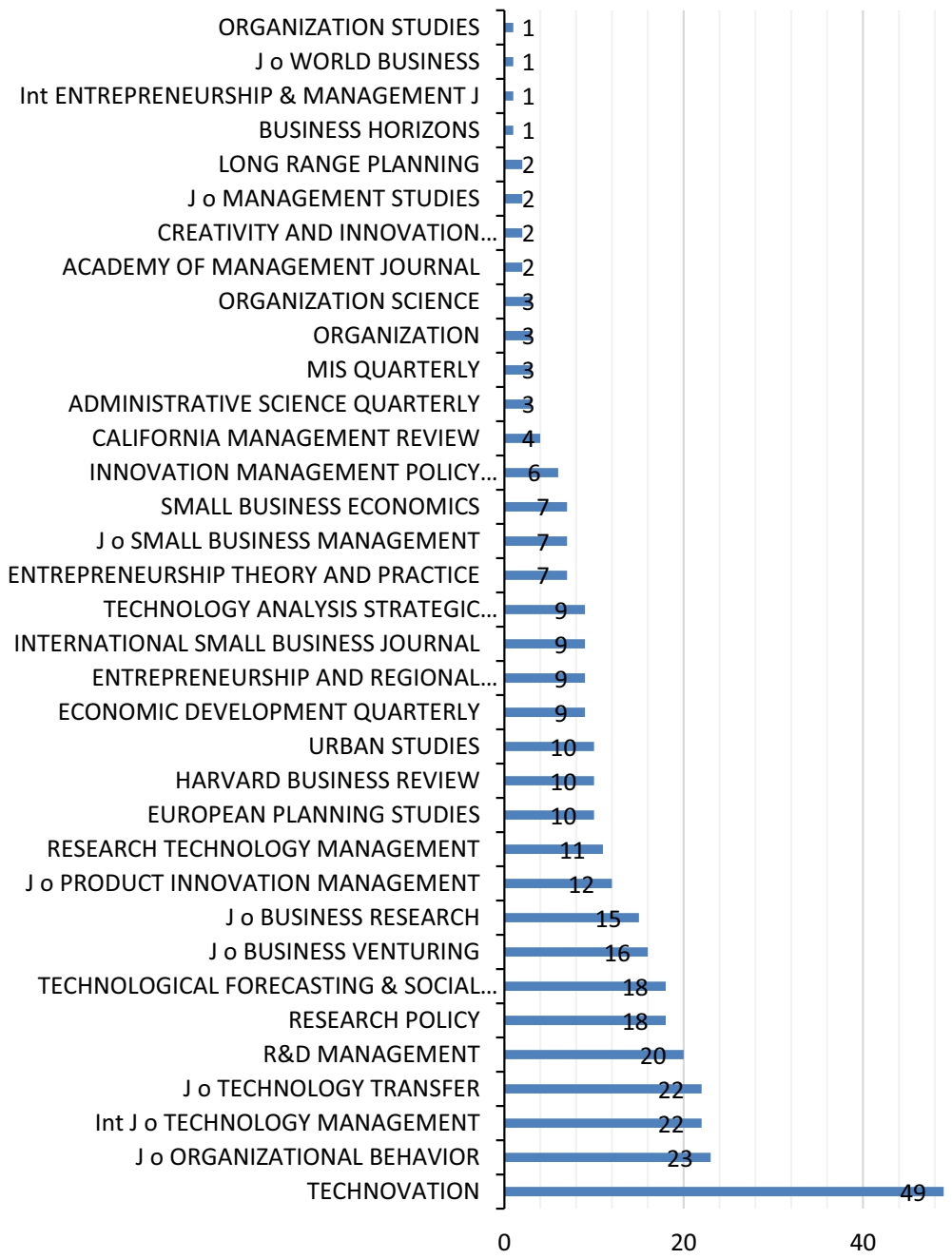

Fig. 1 Number of publications in our sample/Journal

Fig. 2 3-year smoothed publication count and corresponding polynomial trendline

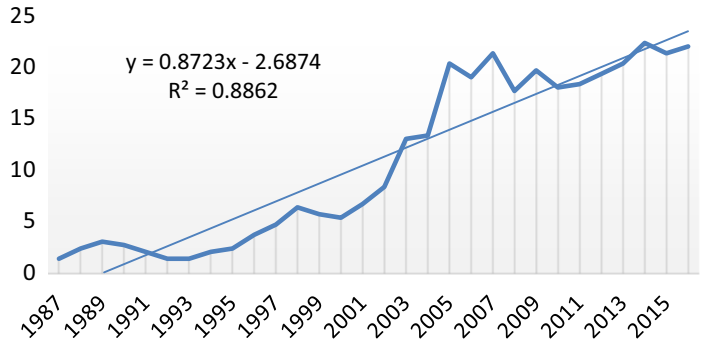




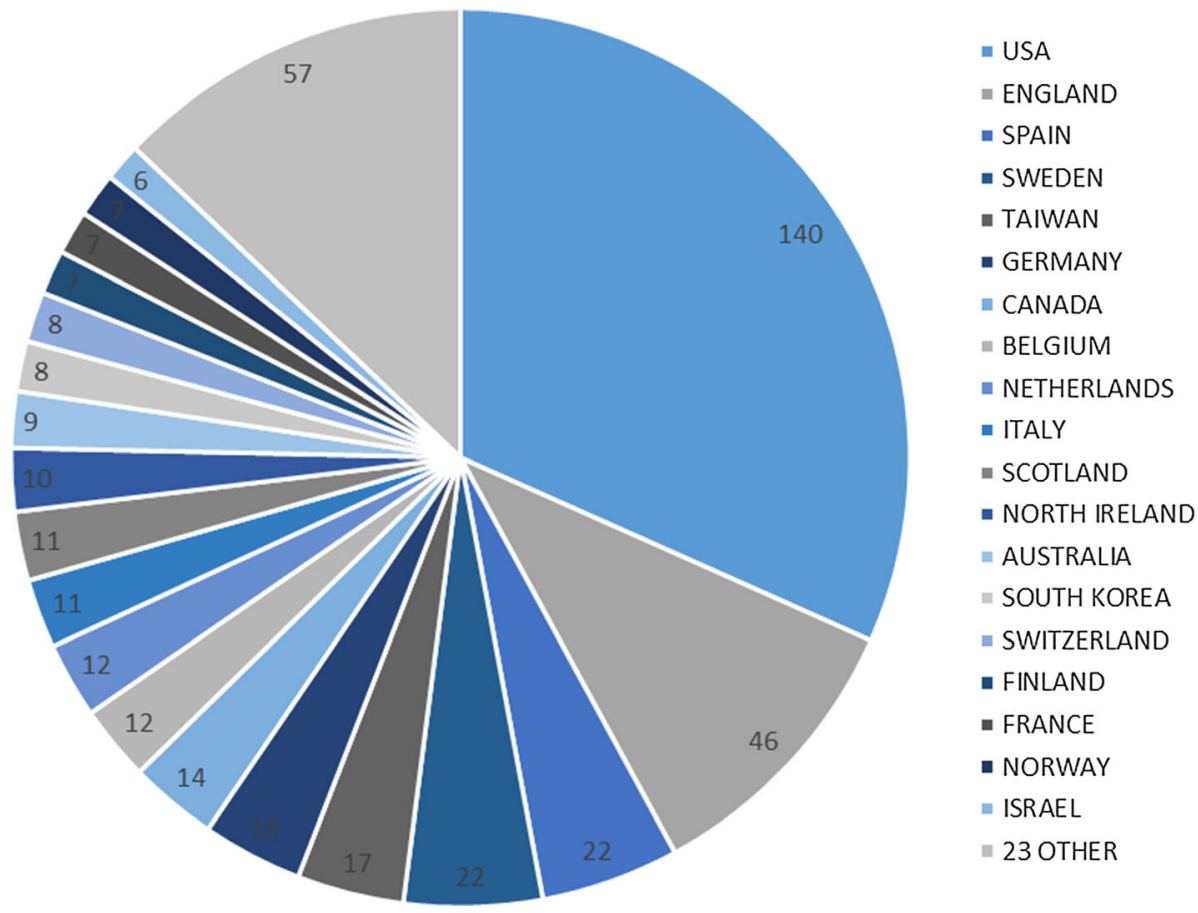

Fig. 3 Research by country (more than one country/article possible)

Table 1 Citation statistics

\begin{tabular}{ll}
\hline Sum of the times cited & 22,286 \\
Sum of times cited without self-citations: & 21,046 \\
Citing articles & 17,254 \\
Citing articles without self-citations: & 16,963 \\
Average citations per item & 27.72 \\
h-index & 73
\end{tabular}

obviously most relevant journals in order to identify false positive results. Following this screening, we could restrict our journal list even further and ended up with a final sample size of 347. On this sample, we performed the bibliometric analysis discussed in the next section (Figs. 2, 3 and (Table 1).

\section{Overview of bibliometric and co-citation analysis results}

Using the freeware online tool hammer.nailsproject.org we conducted a bibliometric analysis and obtained the co-citation node-edge-files. Afterwards, we imported the data to the Gephi 0.9.2 software for the co-citation analysis and visualization of the co-citation network. The assumption behind co-citation analyses is that with an increasing number of shared citations the probability increases that focal papers share a specialized language and specific worldview (Boyack and Klavans 2010). This allows us to conclude that co-citation 


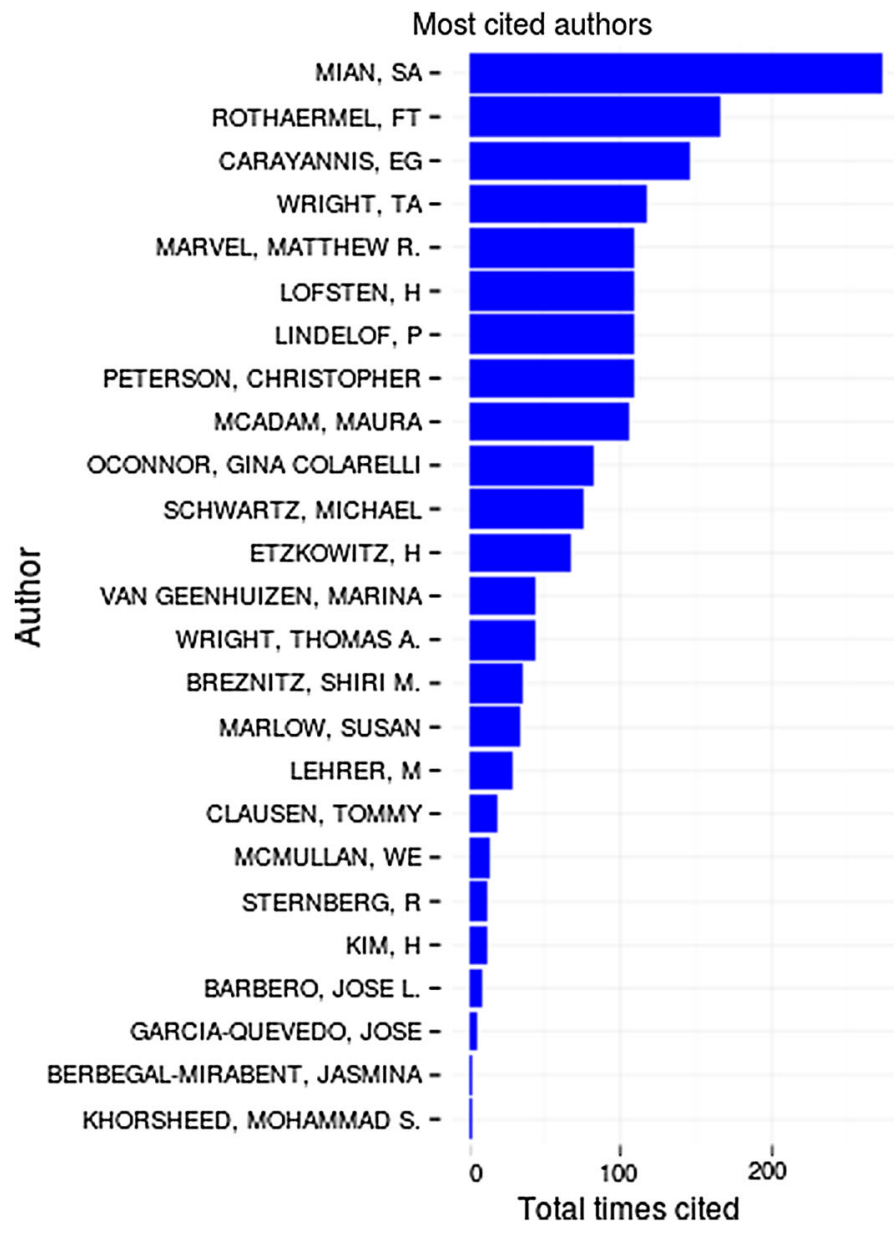

Fig. 4 Most cited authors

clusters treat the topic of interest from a similar perspective and with similar argumentative backgrounds and patterns.

Authors occasionally make errors in citations-above all in the articles before the introduction of citation management software. Thus, we had to screen manually all 11,835 nodes of our nodes table for duplicates. Each duplicate receives only a fraction of the actual citations, leading hence to a severe underestimation of the cited work. Their consolidation is therefore fundamental. Indeed, we found 337 nodes that appeared several times in the table. In many cases, these multiple entries referred to books with different editions over the years. In other cases, authors were included with different versions of their names, e.g. either with both their given names abbreviated or with only the first name without abbreviation Fig. 4. We also found several typos in the volume or year number of journal articles. The entire number of deletions of duplicates amounted to 481 because several entries exhibited multiple different versions. The final number of nodes of the cocitation network hence amounted to 11,354 . We filtered out all entries that received only 
Table 2 Most central articles in co-citation network by cluster

\begin{tabular}{|c|c|c|c|c|}
\hline Cluster & References & InDegree & Closeness & Betweens \\
\hline \multirow{11}{*}{$\begin{array}{l}\text { 1. Business Incubation Core Literature } \\
\text { (green) }\end{array}$} & Mian (1996) & 30 & 1 & $1.69 \mathrm{E}-04$ \\
\hline & Mian (1997) & 26 & 1 & $3.12 \mathrm{E}-04$ \\
\hline & Rice (2002) & 17 & 1 & $5.24 \mathrm{E}-05$ \\
\hline & Aernoudt (2004) & 16 & 1 & $1.39 \mathrm{E}-05$ \\
\hline & Autio and Klofsten (1998) & 11 & 1 & $3.29 \mathrm{E}-05$ \\
\hline & $\begin{array}{l}\text { Sherman and Chappell } \\
\text { (1998) }\end{array}$ & 9 & 1 & $2.00 \mathrm{E}-05$ \\
\hline & $\begin{array}{l}\text { Carayannis and von } \\
\text { Zedtwitz (2005) }\end{array}$ & 7 & 1 & $2.48 \mathrm{E}-05$ \\
\hline & Udell (1990) & 5 & 1 & $2.48 \mathrm{E}-05$ \\
\hline & $\begin{array}{l}\text { Bollingtoft and Ulhoi } \\
\text { (2005) }\end{array}$ & 14 & 1 & $1.85 \mathrm{E}-05$ \\
\hline & $\begin{array}{l}\text { Colombo and Delmastro } \\
\text { (2002) }\end{array}$ & 22 & 0.6963 & $2.48 \mathrm{E}-04$ \\
\hline & $\begin{array}{l}\text { Grimaldi and Grandi } \\
\text { (2005) }\end{array}$ & 15 & 0.6806 & $1.85 \mathrm{E}-04$ \\
\hline \multirow[t]{8}{*}{ 2. Science Parks \& UBIs (blue) } & Clarysse et al. (2005) & 14 & 1 & $1.02 \mathrm{E}-04$ \\
\hline & Markman et al. (2005) & 8 & 0.8077 & $1.37 \mathrm{E}-04$ \\
\hline & Phan et al. (2005) & 17 & 0.6337 & $2.23 \mathrm{E}-04$ \\
\hline & Perez and Sanchez (2003) & 4 & 0.617 & $4.00 \mathrm{E}-05$ \\
\hline & $\begin{array}{l}\text { Rothaermel and Thursby } \\
\text { (2005: 1076) }\end{array}$ & 7 & 0.5371 & $1.15 \mathrm{E}-04$ \\
\hline & Kroll and Liefner (2008) & 1 & 0.4744 & $1.31 \mathrm{E}-05$ \\
\hline & $\begin{array}{l}\text { Rothaermel and Thursby } \\
\text { (2005: 305) }\end{array}$ & 13 & 0.4607 & $1.80 \mathrm{E}-04$ \\
\hline & Lockett et al. (2005) & 4 & 0.4559 & $2.80 \mathrm{E}-05$ \\
\hline \multirow{6}{*}{$\begin{array}{l}\text { 3. Social and Knowledge Capital View } \\
\text { of Incubation (red) }\end{array}$} & Carayannis et al. (2006) & 3 & 1 & $3.31 \mathrm{E}-05$ \\
\hline & $\begin{array}{l}\text { Collinson and Gregson } \\
\text { (2003) }\end{array}$ & 2 & 1 & $1.06 \mathrm{E}-04$ \\
\hline & Tsai et al. (2009) & 1 & 0.7901 & $1.26 \mathrm{E}-05$ \\
\hline & Hughes et al. (2007) & 4 & 0.6457 & $4.47 \mathrm{E}-05$ \\
\hline & $\begin{array}{l}\text { Becker and Gassmann } \\
\text { (2006) }\end{array}$ & 1 & 0.5232 & $7.50 \mathrm{E}-06$ \\
\hline & Tötterman and Sten (2005) & 10 & 0.4769 & $9.69 \mathrm{E}-05$ \\
\hline \multirow{4}{*}{$\begin{array}{l}\text { 4. New Tech-Based Firms in Science } \\
\text { Parks (yellow) }\end{array}$} & Feeser and Willard (1989) & 1 & 1 & $1.13 \mathrm{E}-05$ \\
\hline & $\begin{array}{l}\text { Lofsten and Lindelof } \\
\text { (2001) }\end{array}$ & 9 & 0.6809 & $3.96 \mathrm{E}-04$ \\
\hline & $\begin{array}{l}\text { Lofsten and Lindelof } \\
\text { (2003) }\end{array}$ & 2 & 0.5873 & $1.08 \mathrm{E}-04$ \\
\hline & $\begin{array}{l}\text { Lindelof and Lofsten } \\
\text { (2003) }\end{array}$ & 2 & 0.5556 & $5.25 \mathrm{E}-05$ \\
\hline 5. Technopolis (light green) & - & & & \\
\hline 6. Tech. Centers \& TTOs (orange) & Luria and Wiarda (1996) & 1 & 1 & $3.02 \mathrm{E}-07$ \\
\hline 7. Venture Survival (dark green) & Peña (2004) & 6 & 0.575 & $7.48 \mathrm{E}-05$ \\
\hline
\end{tabular}

First dozen publications of each cluster that have closeness centrality above 0.4. AND in-degree at least 1 


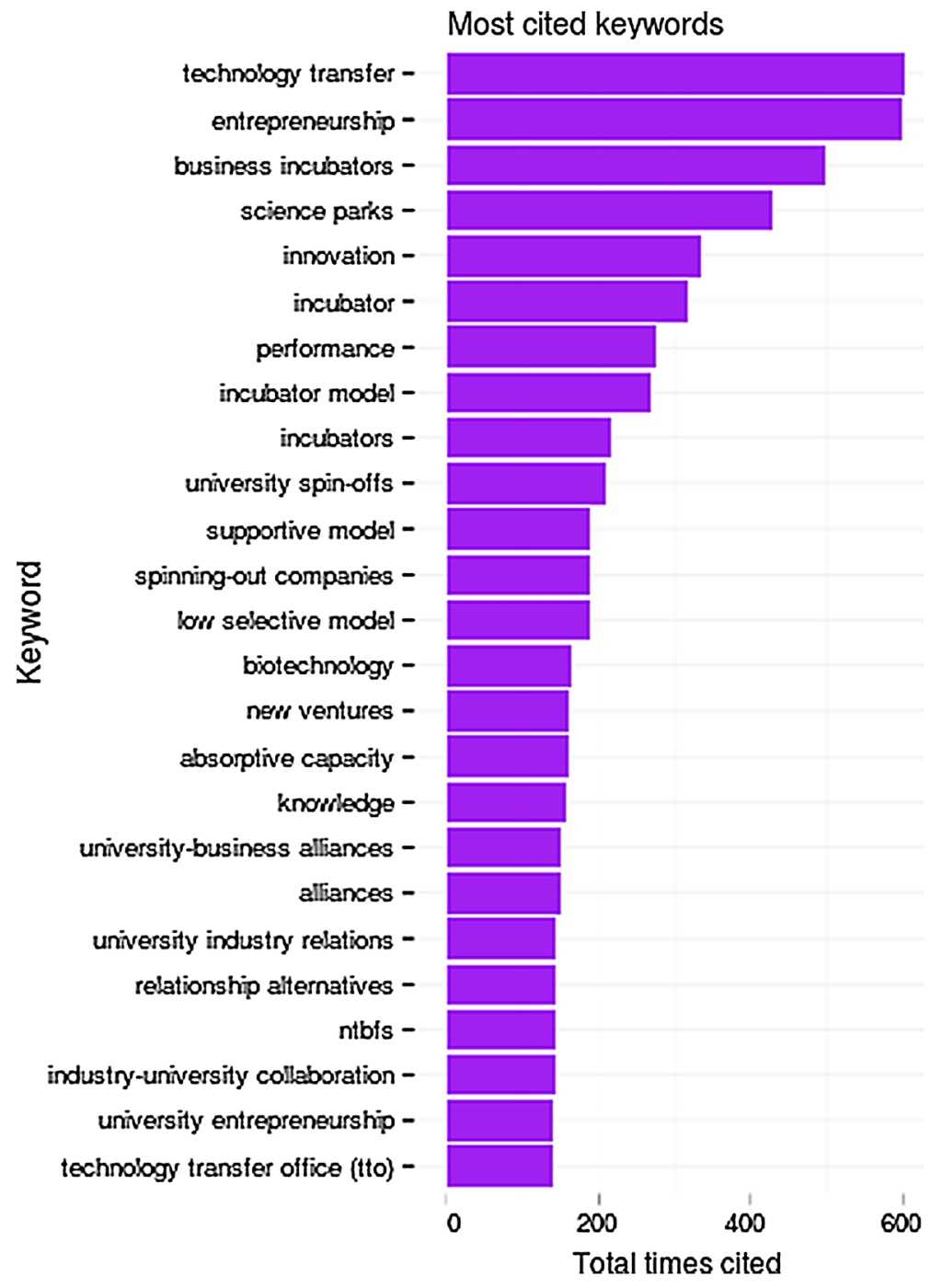

Fig. 5 Most cited keywords

one citation (i.e. in-degree $\geq 2$ ). This reduced the network to a size of 1821 nodes ( $16 \%$ of the total network) with 2842 edges, a diameter of 7 , and an average path length of 2.3 .

Our co-citation analysis revealed seven clusters: (1) business incubation, (2) science parks and university-based incubators, (3) social and knowledge capital view on incubators, (4) new technology-based firms and science parks, (5) technopolis, (6) evaluation, and (7) survival and failure of incubatees (see Table 2 and Figs. 5, 6). While studies in cluster (1) focus primarily on business incubators, the clusters (2-7) show the most relevant research areas that overlap with the research on business incubators. Hochberg (2016) divided research on accelerators roughly into two categories: conceptual description of the accelerator model and empirical accelerator impact assessments. Hackett and Dilts (2004) 


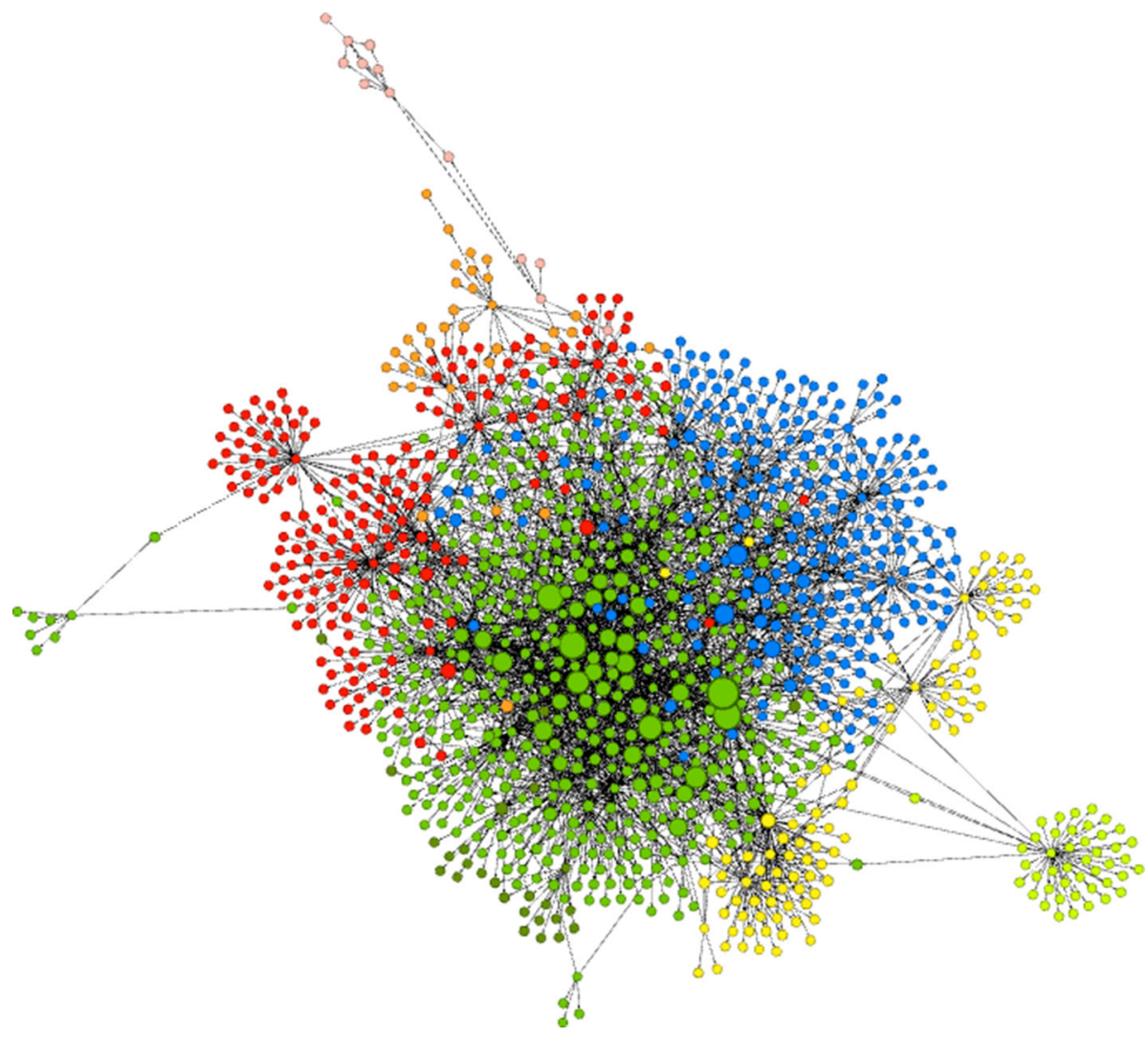

Fig. 6 Largest connected component (node color by cluster; node size by in-degree) (Color figure online)

divide literature into five periods of incubator research, namely in chronological order (1) incubator development studies, (2) incubator configuration studies, (3) incubatee development studies, (4) incubation impact and (5) incubation theory studies. While we agree with Hackett and Dilts (2004) that a slightly more fine-grained distinction between research streams is due, we do not fully agree with their chronological categorization. Based on our review of the papers we analyzed, we find that it is useful to distinguish between the following three streams: (1) studies on origins, definitions and typologies of incubators, (2) studies on the incubation process, and (3) studies on impact and performance. Studies that address issues of definition and characteristics of incubators make up a considerable share of the relevant literature.

\section{Review and summary of the three major research topics}

\subsection{Definitions and typologies of incubators}

There is definitely no scarcity in definitions of incubators. Already 40 years ago, Kuratko and LaFollette (1987) recognized a growing problem defining the concept: "The task of defining what is meant by an incubator has become difficult since the original concept is 
being adapted to fit the needs of the economic areas." (p. 49). In fact, both scholars and practitioners have put forward a plethora of definitions of many similar types of incubators. Adding to the confusion, many concepts evolved before and during the development of the incubator concept and exhibit sometimes a considerable overlap and proximity.

The organizations and institutions of today's entrepreneurial ecosystems (Spigel 2015) are very heterogeneous. Most recently, private independent or corporate for-profit incubators emerge and usually have a focus on start-ups in the ICT and other high-tech sectors (Aerts et al. 2007; Becker and Gassmann 2006; Hackett and Dilts 2004). This new breed of incubators put stronger emphasis on the provision of direct access to capital and specialized services in order to speed up the startups' time-to-market and to bring start-ups into a common network with technological and commercial big players (Grimaldi and Grandi 2005). Large established companies often face difficulties in fostering radical innovation (Christensen 1997), for example due to organizational inertia or conflicting organizational norms and structures (Hannan and Freeman 1984; Tushman and O'Reilly 1996). Hence, firms increasingly try to overcome these difficulties by collaboration with startups through their own corporate incubators and accelerators. In the literature on corporate entrepreneurship, approaches have been identified that resemble what could be called a corporate incubator without bearing that name (Wolcott and Lippitz 2007). These corporate incubators provide most of the services traditional incubators or accelerators provide, but aim at encouraging and helping their own employees to create new business that may then become new business units or spin-offs. The corporate incubator of Phillips has been described as an early example of this kind of corporate entrepreneurship (Ford et al. 2010; Wolcott and Lippitz 2007). However, Ford et al. (2010) describe the Phillips technology incubation program rather as an effective simulation of the venture capital approach than of the business incubator approach. Meanwhile, corporate incubators leveraging external ideas and entrepreneurs increasingly complement (or substitute) these inward-focused ones (Kohler 2016). Corporate incubators hence are means of both outside-in and inside-out open innovation in corporate entrepreneurship (Weiblen and Chesbrough 2015).

Understandably, hence, scholars have not yet settled on a single definition of an ideal type incubator (Albort-Morant and Ribeiro-Soriano 2016). Some studies investigate several of these concepts as a whole and compare them, e.g. science parks and incubators (Ratinho and Henriques 2010) or incubators, technology centers, and universities (RoigTierno et al. 2015). Incubators target ventures, which are in their early development stages, so that the term incubator should not be used interchangeably with the terms science park or technology park, which are generally designed to support more mature firms (Bergek and Norrman 2008). This shows that the definition should not be too narrow since otherwise the immense number of similar concepts would increase even further.

If the definition is too broad, however, it risks including substantial aspects of what research investigates as organizational entrepreneurship. In fact, Cooper (1985, p. 76) notes: "Every organization might be viewed as a potential incubator, influencing its employees in a variety of ways that make them more or less likely to leave and start new firms." A narrower definition allows the distinction of classical business incubators from other forms of business incubating-organizations like accelerators. Accelerators usually are fixed-term, cohort-based programs providing education, monitoring, and mentoring to start-up teams (usually not single entrepreneurs) and connecting them with experienced entrepreneurs, venture capitalists, angel investors and corporate executives and preparing them for public pitch events in which graduates pitch to potential investors (Cohen 2013; Cohen and Hochberg 2014; Hochberg 2016). 
We found a broad range of broader and narrower definitions of incubators in the literature we reviewed (see Table 3). While for a long time the physical collocation of incubatees has constituted a central defining characteristic of business incubators, this feature is lacking in some more recent definitions due to the increasing focus on counseling

Table 3 Definitions of business incubators

Definition

"A facility which promotes the early stage development of a for-profit enterprise [w]ithin the confines of a building (...)"

"Real estate projects with shared space and administrative arrangements [and] organize the business development process"

"Seeks to effectively link talent, technology, capital and know-how in order to leverage entrepreneurial talent and to accelerate the development of new companies"

"A facility with adaptable space which small businesses can lease on flexible terms and reduced rents [where] Support services are available and shared"

"Large buildings operated to nurture young companies by providing low-rent space, shared office services and management advice"

"Centralized physical facilities that 'incubate' new and small ventures by providing them with varying support services and other assistance."

"Are multi-tenant buildings providing affordable, flexible space, and a variety of office and support services which share a common purpose: to nurture small fledgling firms into healthy businesses"

"Locally based institutions that provide shared physical space and business support services to new and young firms"

"[Organizations that] offer fledgling companies a number of benefits-office space, funding, and basic services such as recruiting, accounting, and legal-usually in exchange for equity stakes"

"Producer' of business assistance programs. (...) companies and the incubator staff are co-located in the same facility"

"An enterprise that facilitates the early-stage development of firms by providing office space, shared services and business assistance"

"Evolving innovative organizational form that is a vehicle for enterprise development"

"Any organization that provides access to affordable office space and shared administrative services"

"Property-based organizations with identifiable administrative centers focused on the mission of business acceleration through knowledge agglomeration and resource sharing"

"Organisations that supply joint location, services, business support and networks to early stage ventures"

“Organizations who's purpose it is to support the creation and growth of new businesses, by supplying a shared office environment and agglomeration of new and small businesses"

"Tools to accelerate the creation of successful entrepreneurial companies"
References

Plosila and Allen (1985)

Campbell et al. (1985)

Mcadam and Marlow (2007), Smilor and Gill (1986)

Kuratko and LaFollette (1987)

Lumpkin and Ireland (1988)

Udell (1990)

Weinberg et al. (1991)

Markley and McNamara (1995)

Hansen et al. (2000)

Rice (2002)

Hackett and Dilts (2004)

Peters et al. (2004)

Bollingthoft and Ulhoi (2005)

Phan et al. (2005)

Bergek and Norrman (2008)

Honig and Karlsson (2010)

Bruneel et al. (2012) 


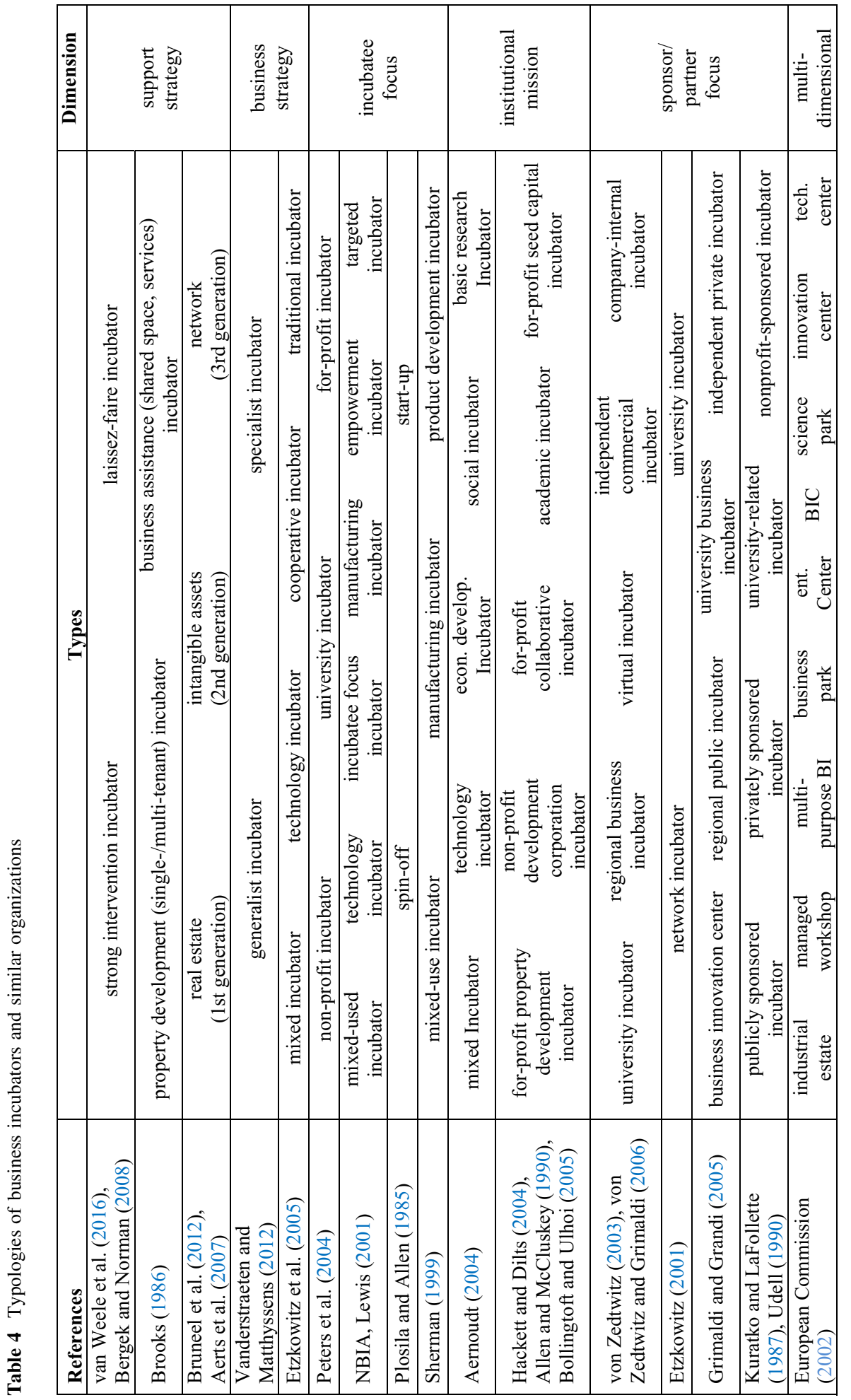


and support services and the advent of virtual business incubators. On a most fundamental level, definitions of incubators refer to these as projects, tools, facilities, buildings, enterprises, organizations or most broadly institutions. Defining business incubators as organizations or institutions is broad enough to include both public and private incubators, but defining them as organizations rather than institutions emphasizes that they are actively managed. Moreover, we observe that definitions build on descriptions of incubators' goals (e.g. facilitating the growth of startup firms), behavior/business model (e.g. the offering of shared office space or business support services), or both. However, goals might be different for different types of incubators. While publicly sponsored incubators often are more interested in job creation, private-independent incubators emphasize profitability, and private-corporate incubators tend to focus on contributions to their mother corporation's strategic goals. The most reconcilable approach seems to be defining incubators based on the minimal common ground business model that distinguishes them from other players in the entrepreneurial ecosystem. Therefore, we define a broader (business-incubating organizations) and a narrower (business incubators) definition:

Business incubating-organizations (in the broader sense) are those that support the foundation and/or growth of new businesses as a central element of their organizational goal.

Business Incubators (in the narrower sense) are business-incubating organizations that support the establishment and growth of new businesses with tangible (e.g. space, shared equipment and administrative services) and intangible (e.g. knowledge, network access) resources during a flexible period and are funded by a sponsor (e.g. government or corporation) and/or fund themselves taking rent (or less frequently equity) from incubatees.

The first scholarly typology differentiates between publicly sponsored, nonprofitsponsored, university-related, and privately sponsored incubators (Kuratko and LaFollette 1987). Kuratko and LaFollette (1987) summarize from previous literature ten different characteristics in which private and public incubators may differ. These include their tenant capacity and selection, governance and exit policy, rent and complementary revenue

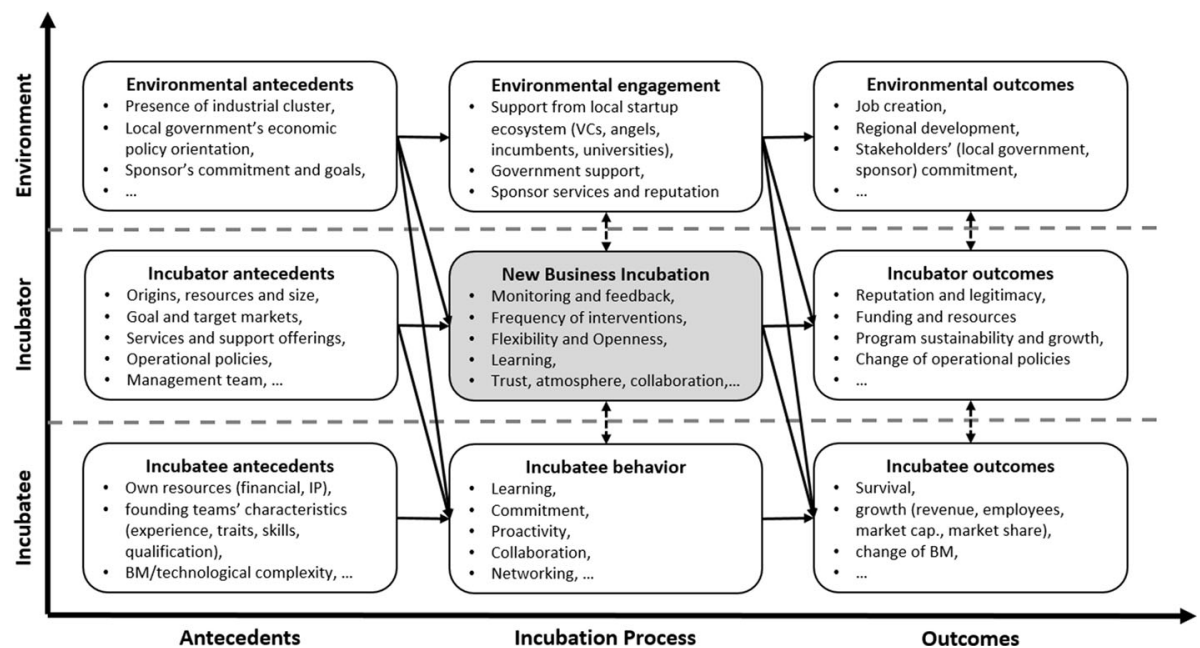

Fig. 7 Multi-level antecedents and outcomes of business incubation 
sources, type of sponsors, services offered, size of staff and the induced growth in jobs and sales. While public incubators receive their agenda from their governmental sponsors and hence usually focus on job creation, private incubators focus on return on investment and their tenants' financial success.

Von Zedtwitz (2003) identified five basic archetypes according to their competitive focus and strategic objective, while Clarysse et al. (2005) differentiated according to goals and strategies. University incubators and regional business incubators serve a scientific or a local community, respectively, and they fulfill primarily a public mission. In contrast, virtual incubators, independent commercial incubators and company-internal incubators are oriented towards making profits or promoting the objectives of their parent company. Similarly, Grimaldi and Grandi (2005) use the institutional mission as one characterizing variable to distinguish between two types of incubator models, i.e. business innovation centers and regional public incubators on the one hand and private incubators on the other hand (university business incubators are situated somewhere between the two models). We summarize these and further typologies that we could identify in Table 4 below.

\subsection{Incubation process}

Hackett and Dilts (2004) describe the selection of incubatees, their monitoring and assistance as well as resource infusion as core elements of the incubation and acceleration process. Similarly, for Bergek and Norrman (2008) selection, business support, and mediation are main distinguishing components of incubators, but they mention infrastructure and graduation as further components. While most incubators are similar regarding their infrastructure and graduation policies, they differ widely in their selection strategies, business support services and mediation offering (Bergek and Norrman 2008). In the following subsections, we review the literature on the incubation process, which we summarized visually in Fig. 7.

\subsubsection{Search and selection}

Maintaining a steady flow of quality proposals is a key factor for incubator success (Patton et al. 2009). Therefore, incubators engage in marketing activities to build awareness and establish a name within the targeted industry so as to attract a sufficient number of applications (Aaboen 2009). To filter the right candidates, incubators have to choose criteria for selecting their incubatees. In particular, for-profit incubators review candidates rigorously by applying criteria that are similar to those applied by venture capitalists (Ford et al. 2010; von Zedtwitz 2003). Beyond these criteria, however, corporate incubators consider strategic alignment between their startup portfolio and their parent company as a relevant selection criterion, which is often more relevant than expected immediate financial returns. Lumpkin and Ireland (1988) identify three groups of screening criteria, which include the experience of the management team, financial strength as well as market and personal factors. Using this study as a basis, Aerts et al. (2007) describe the screening practices of European business incubators. They distinguish between financial screeners focusing on financial rations, team screeners emphasizing personal characteristics of the management team, market screeners primarily valuing market factors, and balanced screeners. They find that $61 \%$ of incubators are market screeners and $27 \%$ are team screeners, while financial and balanced screeners are a rare species.

Bergek and Norrman (2008) provide in their framework a two-by-two matrix to classify selection strategies. Firstly, they differentiate between idea-focused and entrepreneur-focused selection. That means that the primary criterion of selection is either viability of 
ideas or personal characteristics, experiences and skills of entrepreneurs. Secondly, they differentiate between "picking-the-winners" and "survival-of-the-fittest" selection. The former refers to application of rather strict criteria in order to identify few potentially successful ventures ex ante, while the latter denotes the application of more flexible criteria in order to accept a larger number of firms and then leave it to the market to separate winners from losers. Combining a selection approach from the first dimension with one from the second dimension implies four possible selection strategies.

When selecting new incubatees, incubators also need to consider the dynamics that emerge due to the nature of the overall incubatee portfolio they developed. As tenants in specialized incubators are often active in the same markets, they fear competition and may be more reluctant to share information and network contacts with each other. In addition, if tenants share a similar knowledge base, cross-fertilizations with other technology or business fields are less likely to occur (Schwartz and Hornych 2008). Tötterman and Sten (2005) in fact recommend that incubators aim for a mix of companies that represent different sections of the value-chain or companies that are in different life-cycle stages.

\subsubsection{Business support}

Business support services gained increasing prominence and relevance in the business models of incubators, where the provision of office space and facilities today is mostly secondary. Common areas covered include sales, accounting, law, contracts, patent strategies, presentation technique, advertising, media and negotiation (Aaboen 2009). The choice of incubatees affects the mix of services provided and vice versa, as the incubator aims to maximize the fit between its services and the specific needs of the new businesses (Hackett and Dilts 2004). The incubator monitors the performance of their tenant firms and provides feedback to help contain risk by preventing them from making mistakes. When problems arise, the incubator can provide business support services as needed. Incubators can provide this kind of monitored business assistance most effectively through frequent counseling interactions, because this strengthens the relationship between the incubator management and the incubatees (Scillitoe and Chakrabarti 2010). Rice (2002) finds that interaction between incubator managers and entrepreneurs is fundamental for success. The more time incubator managers spend on co-production-in general as well as in each specific co-production episode-and the broader the modalities they use, the higher is their impact. However, for this co-production to work, entrepreneurs need to be aware of their startup's gaps in knowledge, competencies, and resources, to recognize the potential of the incubator to fill those gaps.

Bergek and Norrman (2008) find that some incubators follow a strong intervention approach, while others choose a laissez-faire regime. Interventionists see their role as managers who guide ventures through the incubation process by the steady hand and sometimes even supply them with complete management teams or require them to do certain trainings. In contrast, laissez-faire incubators perceive themselves as external facilitators of a process that incubatees manage primarily by themselves. These incubators hence supply resource and assistance only on incubatees' request.

McAdam and McAdam (2008) explore the use of incubator resources at different lifecycle stages. They find that the propensity to make use of the resources and support increases throughout the lifecycle and as young firms search for independence and autonomy. At some point, incubatees graduate and move out of the incubator. The incubator management is to specify under which circumstances incubatees have to leave the incubator and help them develop appropriate exit strategies. 


\subsubsection{Mediation}

Whenever incubators lack resources required by an incubatee, like for example specialized, in-depth technical expertise, they can assist incubatees through networking activities (Scillitoe and Chakrabarti 2010). For instance, Rubin et al. (2015) examine different knowledge agents who surround the incubators and examine knowledge flows taking place in the context of the interrelationships with the incubatees. They distinguish between technological knowledge bearers, market knowledge bearers as well as financial resources bearers.

Incubators manage both an external and an internal inter-organizational field, to which they connect their incubatees (Weinberg et al. 1991). Externally, the incubator should foster business connections between tenants and outside firms, government agencies, and other sources of commercial relevance. Internally, the incubator should facilitate relationships among a pool of resident businesses and administrative staff of the incubator.

While research has initially ignored the role of informal networks, Rothschild and Darr (2005) highlight the role of informal networks of innovation. In their case study of a research university and an affiliated technological incubator they find that a variety of strong and meaningful ties exist, which are to a large degree based on informal contacts between the parties involved. On this basis, a two-way flow of knowledge and goods, from which both organizations benefit, takes place. Patton et al. (2009) find that such possibility to meet and interact with like-minded individuals motivates founders to join the incubator and that the synergies within such an internal support network is a key factor for successful incubation.

Bollingtoft (2012) observes a variety of different networking and cooperation activities among tenants, which appear to support the development of knowledge as well as the companies' growth. Thus, the role of incubators is to facilitate these activities; important conditions include physical proximity and attracting entrepreneurs with a positive attitude towards knowledge sharing and cooperation, as well as a willingness to share values and norms. Therefore, after the exit, the incubator should seek to keep in touch with their alumni so they remain part of the incubator's community (Tötterman and Sten 2005).

\subsection{Performance and potential impacts}

The evaluation of performance and potential impacts of incubators also has received considerable interest in previous research. Available studies are heterogeneous, using different methodological approaches and focusing on different measures. Some studies investigate the impact that activities of incubators can have at the individual firm level; others estimate impacts at a macroeconomic level. In addition, some frameworks rely on several dimensions to provide a more holistic picture of incubator performance.

Researchers, who seek to evaluate impact of incubators, face several difficulties. One difficulty concerns the problem to get good and reliable data, because entrepreneurs are often reluctant or too busy to share information, do not keep good records, or engage in self-aggrandizement when providing information (Udell 1990). Bergek and Norrman (2008) define incubator performance as the extent to which incubator outcomes correspond to incubator goals, but the evaluation of incubators' performance becomes further complicated as goals vary across institutions. It is particularly interesting to assess the impact of incubators on its firms compared to non-incubated firms. However, incubator managers have an incentive to select firms that are likely to succeed and filter out weaker candidates. 
As a result, the cohort of incubated firms is not representative of the overall population and such selection bias may lead to an overestimation of incubator effectiveness (Udell 1990; Stokan et al. 2015). Furthermore, we consider selection itself as a central element of the incubation process and as such a factor contributing to the incubator success. Disregarding selection would make it impossible to discriminate between incubators that are bad at selection but good at further support and those that are strong in selection but weaker at further support. Finally, there is significant controversy about which measures are best suited to measure the performance of incubators.

\subsubsection{Incubators' impact at the level of the new firm}

Adopting the definition of incubators as organizations that help new firms survive and grow, most studies assess incubators' performance in terms of new venture creation and the growth and survival rate of new businesses (Colombo and Delmastro 2002; Peña 2004; Schwartz 2009; Stokan et al. 2015). The majority of these studies is quantitatively oriented and relies on data from questionnaires. In general, the number of graduates is a very rough measure of the ability of the incubator to accelerate the entrepreneurial process (Peters et al. 2004). While graduation tends to be easy, it is more difficult for young firms to prosper in the long term. Schwartz (2009) observes that the discontinuation of support occurring after startup graduation has a negative effect on startup survival, which lasts up to 3 years after leaving the incubator.

One frequently used approach to compare the performance of a group of incubated firms with a comparable cohort of non-incubated firms, is to use matching techniques to control for potential selection bias. Colombo and Delmastro (2002) use this approach to evaluate the effectiveness of Italian technology incubators. They compare a sample of 45 firms in technology incubators located in science parks and business innovation centers to a control sample of off-incubator firms. Their results indicate that input and output measures of innovative activity differ only marginally. However, they find that on-incubator firms have entrepreneurs with better human capital on board, show higher growth rates, and find it easier to get access to public subsidies. They also find these firms to perform better in terms of adoption of advanced technologies, aptitude in participating in international R\&D programs, and establishment of collaborative arrangements. Moreover, also Stokan et al. (2015) find positive effects of incubators' activities on firm growth. In particular, they show that incubators have a significantly positive effect on the firm's number of employees and that incubated firms receive five times as many business services as their non-incubated cohort. Schwartz (2013) concentrates on long-term business survival tracking a sample of firms within a publicly initiated incubator over a period of 10 years and comparing their performance to a control group of comparable startups that did not receive support from an incubator. However, results do not indicate that firms located in incubators have higher chances of long-term business survival than comparable firms located outside incubators do. To the contrary, he finds indications for a negative effect in some cases.

Another group of studies focusses on the impact evaluation of incubator practices and services with regard to the performance of young firms. Aerts et al. (2007) investigate the link between screening practices of incubators and performance. They find that screening based on a balanced set of factors correlates with a higher tenant survival rate. However, while this is useful to know for incubator managers as it indicates that screening works, it tells little about the utility of incubator support since screening practices introduce heavy selection bias if compared to a group not equally screened. The study by Peña (2004) aims to find out the extent to which the support received by entrepreneurs from incubator centers 
is critical for young firms to survive the difficult initial years. However, the results indicate that the majority of variables related to assistance offered from incubators is non-significant. Peters et al. (2004) focus on the impact of incubator services, including infrastructure, coaching and networks, on the graduation rates of incubatees. They find that merely comparing types of services offered will not be sufficient to explain differences in graduation rates among incubators. Instead, they conclude from their interviews that consideration of selection processes as well as knowledge as a resource acquired through networks and interactions among co-tenants is key to understand incubators' performance in terms of graduation rates. Networks also play a role in the study of Rothaermel and Thursby (2005), in which the authors investigate the effect of university linkages on incubator firm failure and graduation, with linkages being licenses or professors on the firms' senior management team. They find support for their hypotheses that a university link reduces probability of new venture failure, but retards the firm's graduation from the incubator.

Lasrado et al. (2016) investigate whether firms graduating from university incubators attain higher levels of post-incubation performance than firms participating in non-university affiliated incubators do. Results show that university incubated firms do indeed benefit from their relationship with university incubators. After firms graduate from the university incubator, the number of jobs and sales grew over time, showing that their performance continually improves. Moreover, the authors find that university-incubated firms generate greater employment and sales than non-incubated firms, which indicates superior performance.

In addition to practices and services provided by incubators, further factors may influence their performance. Barbero et al. (2012) point out that performance differs according to the type of incubator. They differentiate between four types of incubators: private incubator, basic research incubator, university incubator and regional development incubator. Investigating 90 incubators in Andalucía, they find that some types perform better in specific performance measures, while others perform worse. They use five categories of performance measures, which include firm growth, participation in R\&D programs, input $\mathrm{R} \& \mathrm{D}$, output $\mathrm{R} \& \mathrm{D}$ and employment generation cost. Regional development incubators do not fulfill their objectives. University incubators perform satisfactorily. Private incubators and basic research incubators performance is outstanding. In a subsequent publication, Barbero et al. (2013) find evidence for significant differences within archetypes concerning the type of innovation generated. Mas-Verdu et al. (2015) employ a fuzzy-set qualitative comparative analysis to analyze the role of incubators in interaction with other factors such as the degree of business innovation, size, sector, and export activity. Their results show that incubators on their own cannot affect business survival likelihood. Instead, combinations with other factors are necessary, e.g. new companies that are large or operate in certain sectors show a higher rate of survival.

\subsubsection{Incubators' impact at the macroeconomic level}

Besides the impacts at the level of the individual firms, incubators' activities may also have direct and indirect effects on the local, regional or even national economy. Indirect effects often occur because incubated firms create links to other actors and thereby stimulate their economic activities. Researchers use both regional macroeconomic models (Sherman and Chappell 1998) and input-output models (Markley and McNamara 1995) to estimate employment and wages directly attributable to incubated firms as well as the indirect 
effects resulting from their impact on economic activities of other companies. Both articles find that employment and income multiplier effects occur.

Among the most important direct macroeconomic effects of incubators are their significant fiscal impacts, as higher local income results in higher local tax revenue. Thus, results strongly indicate that incubators can be an effective economic development tool. Ratinho and Henriques (2010) in fact investigated whether an entire population of incubators and science parks contributes to economic growth in a converging economy (in this case Portugal). However, they find that the contribution to job creation and economic growth is barely visible and that activities of incubators (and science parks) have, at best, a local impact.

\subsubsection{Multi-dimensional frameworks for incubator performance evaluation}

Some scholars developed multidimensional frameworks as a basis for a more holistic evaluation of incubator performance. These frameworks tend to be rather qualitative in nature and primarily rely on interview data for comparative evaluations of several incubator cases. Mian (1994) provides one of the first frameworks for assessing the practices and performance of incubators. He identifies 13 key characteristics based on a review of incubator studies. These include the origin of facilities, the incubator objective, organizational design, governance, tenant performance reviews, institutional support, staffing, funding resources, technologies targeted, personal traits of tenant entrepreneurs, strategic operational policies, services and their value added, as well as the survival and growth of tenant firms. He uses this list to evaluate by comparison six university-sponsored incubator programs and finds them all exhibiting positive outcomes, although to very different degrees. He concludes that university-sponsored technology incubators should set reasonable objectives and implement management practices that are conducive to tangible results. In a subsequent publication, Mian (1997) updates the list of characteristics and regroups them into three sets. The first set consists of performance outcomes, the second set includes management policies and their effectiveness and the third set comprises services and their value added. The multiple dimensions of this framework that Mian (1997) suggests in order to evaluate performance are program growth and sustainability, tenant firm's survival and growth, contribution to the sponsoring university's mission, as well as community related impacts.

As a response to a lack of incubatee perspective in this latter study, Chan and Lau (2005) propose a modified framework that captures the effects on technology firms throughout their venture path. They identify nine criteria from the literature and use these to compare performance from the incubatees' perspective. These criteria are pooling resources, sharing resources, consulting/counseling services, public image, networking, clustering, geographic proximity, costing, and funding. They find that the effect of each incubator characteristic on the incubator's tenants depends on the tenants' stage of development.

Most recently, Fonseca and Chiapetta Jabbour (2012) developed a framework with a particular focus on evaluation of the incubators' and the incubated firms' environmental performance. The framework comprises of seven variables, i.e. green building and facilities, green screening process, environmental training, energy management, water resource management, promoting green management, tenants with green proactivity. For each variable, scores are given and the total score allows the classification of incubators according to "levels of environmental maturity". They apply the framework to six 
Brazilian incubators and find that in all except one case environmental management is of little importance.

\section{Research gaps and agenda}

The incubator landscape has evolved over the course of time from mere real estate projects or university spin-off facilities to complex, business development-support organizations with a broad range of different business models. In recent years, the business incubation industry has witnessed a significant increase in the number of corporate incubators and accelerators. In fact, the number of accelerators increased from the first accelerator in 2005 (Y Combinator) and a dozen in 2008 to about 180 in 2013 in the US and up to an estimated 3000 world-wide (Hochberg 2016). There are no precise numbers regarding how many of these have corporate sponsors, but there are several well-known examples, like the AT\&T Aspire Accelerator, Axel Springer Plug and Play Accelerator, the Disney Accelerator, or Microsoft Ventures Accelerator. Likewise, more and more incubators with corporate sponsors emerge as well, like the Jaguar Land Rover TechIncubator, the Breed Reply IoT advanced Incubator, or the Bayer CoLaborator.

Due to the recency of these phenomena, there is only a small number of publications. Hence, there are many open questions. Most importantly, corporate incubators and accelerators raise new issues regarding their relationships, not only with their incubatees, but also with their sponsor, which has very different interests than the common public sponsors had. An important aspect of any corporate incubator and accelerator project, whether leveraging internal or external resources, seems to be the establishment of separate organizational units in order to avoid turf battles. Wolcott and Lippitz (2007) call the internal version of this the "producer model". This organizational separation is particularly important where the goal is creating radical innovations that bear the potential to not only cannibalize more or less but also completely disrupt the business model of one or more of the corporations' business units. This consequence of innovations, this Schumpeterian creative destruction, is often at the root of the innovator's dilemma (Christensen 1997). A relatively old approach to achieve this is the skunkworks model of innovation (Jenkins 2001). We therefore consider the skunkworks approach to successfully develop and commercialize radical innovations as an early version at least of company builders, but to some degree also of corporate accelerators. In fact, we think that it is important to show what is actually new about corporate accelerators as a means of corporate venturing and entrepreneurship. However, to date there is still only very limited research on this phenomenon. While corporate incubators offer different kinds of services, there is not much research on what they expect to receive back. In particular, research on differences between corporate and private but independent incubators is highly relevant, but missing. How can corporate incubators align interests between the sponsoring corporation and the incubatees? What are the consequences of the strong asymmetry between a big incumbent corporation and incubatees? Can corporate incubators realize more synergies than private or public incubators? How do they differ in terms of outcomes such as graduation rate, survival rate, or sales growth?

Another important research gap consists in the consideration of quantitative multi-level studies. As we showed above in Fig. 7, research can and does investigate antecedents and outcomes of business incubation at least at the three levels of incubatees, incubators, and their environments and communities. However, the interactions between and dynamics 
across these levels are not trivial and not well understood. This gets even more relevant in light of the discussed emergent phenomena of corporate incubators, because they introduce the corporation as a new and dominant stakeholder in the incubation process.

Finally, we recognize in the theoretical foundations of incubator research an additional research gap. About a decade ago, many studies did not use a consistent theoretical lens (Hackett and Dilts 2004). This has changed and Mian et al. (2016) find several theoretical lenses through which to consider incubators, ranging from social network and social capital theory over institutional theory, structural contingency theory to stakeholder view and resource based view. Considering in particular the first research gap regarding corporate incubators, the consideration of open innovation as a theoretical lens for incubation research is promising (Weiblen and Chesbrough 2015). While open innovation helps to understand the corporate incubator from the perspective of its corporate sponsor, literature on absorptive capacity (Cohen and Levinthal 1990) could help to explain advantages that incubators have due to their close ties to a corporate sponsor.

\section{Limitations and conclusion}

In this systematic review study, we carried out a bibliometric and co-citation analysis. Compared to unsystematic reviews, systematic reviews offer the advantage that they do not introduce an unconscious bias of the researchers carrying out the review. On the other hand, it is also true that our study suffers some usual limitations. Above all, we are limited to the literature that we found in one database, the ISI Web of Science (WoS). Although this is the most comprehensive database available for this kind of study, it is by no means exhaustive. Hence, while we can exclude unconscious bias on our site, we cannot exclude that we missed out some relevant work that is not covered by ISI WoS. In this regard, however, our approach is no different to that of previous reviews, like for example that of entrepreneurship research in general by Schildt et al. (2006).

The same holds for the definition of the research objective and selection of search terms, which is another limitation of this review. However, with whatever care selecting these terms, systematic reviews can never pretend to cover exhaustively such a vast field. What they can do, however, is to provide an overview of the current state and to point to future directions of the field.

The analysis allowed us to make four distinct contributions to the field of business incubation research. First, we identify the majority of the most relevant extant research, measure each contribution's impact in terms of citations and identify the most central papers in the co-citation network. We could show that the field of business incubation matured into a recognizably distinct field from that focused on science and technology parks, which only investigates one particular form of incubators, namely university business incubators. We could also show that the business incubation literature using social capital theory and social network theory as their theoretical lens grew so much in the last decade that it constitutes an own cluster. Second, we summarized a range of definitions and typologies of business incubators and showed commonalities and differences as well as the progressively changed understanding of the primarily defining characteristics. We derive from our research a reconciling definition of the concept of business incubator in both the broader and the narrower sense. Based on this definition, we show key features of business incubators compared to other related players in the entrepreneurial ecosystem. Third, we provide an overview of key findings from extant literature with a focus on the more central 
papers and provide a multi-level framework to consider antecedents and outcomes of business incubation as a dynamic process. Fourth, while systematically reviewing the literature, we have discovered recent trends and new topics in both theory and practice. We identify several persisting research gaps in the literature and suggest a range of related questions for a research agenda.

Acknowledgements We greatly appreciate the helpful discussions with and feedback from Sebastian Spaeth and Luca Sabini as well as proofreading by Alexandra Christiansen. Sabrina Korreck thankfully acknowledges funding by the Landesforschungsförderung Hamburg as part of the Project "Open Foresight".

Open Access This article is distributed under the terms of the Creative Commons Attribution 4.0 International License (http://creativecommons.org/licenses/by/4.0/), which permits unrestricted use, distribution, and reproduction in any medium, provided you give appropriate credit to the original author(s) and the source, provide a link to the Creative Commons license, and indicate if changes were made.

\section{References}

Aaboen, L. (2009). Explaining incubators using firm analogy. Technovation, 29(10), 657-670. https://doi. org/10.1016/j.technovation.2009.04.007.

Aernoudt, R. (2004). Incubators: A tool for entrepreneurship? Small Business Economics, 23, 127-135.

Aerts, K., Matthyssens, P., \& Vandenbempt, K. (2007). Critical role and screening practices of European business incubators. Technovation, 27(5), 254-267. https://doi.org/10.1016/j.technovation.2006.12. 002 .

Albort-Morant, G., \& Ribeiro-Soriano, D. (2016). A bibliometric analysis of international impact of business incubators. Journal of Business Reserach, 69(5), 1775-1779.

Allen, D. N., \& McCluskey, R. (1990). Structure, policy, services, and performance in the business incubator industry. Entrepreneurship Theory and Practice, 15(2), 61-77.

Autio, E., \& Klofsten, M. (1998). A comparative study of two European business incubators. Journal of Small Business Management, 36(1), 30-43.

Barbero, J. L., Casillas, J. C., Ramos Garcia, A., \& Guitar, S. (2012). Revisiting incubation performance: How incubator typology affects results. Technological Forecasting and Social Change, 79(5), 888-902. https://doi.org/10.1016/j.techfore.2011.12.003.

Barbero, J. L., Casillas, J. C., Wright, M., \& Ramos Garcia, A. (2013). Do different types of incubators produce different types of innovations? Journal of Technology Transfer, 39, 151-168.

Becker, B., \& Gassmann, O. (2006). Corporate incubators: Industrial R\&D and what universities can learn from them. Journal of Technology Transfer, 31, 469-483.

Bergek, A., \& Norrman, C. (2008). Incubator best practice: A framework. Technovation, 28(1-2), 20-28. https://doi.org/10.1016/j.technovation.2007.07.008.

Bollingtoft, A. (2012). The bottom-up business incubator: Leverage to networking and cooperation practices in a self-generated, entrepreneurial-enabled environment. Technovation, 32(5), 304-315.

Bollingtoft, A., \& Ulhoi, J. (2005). The networked business incubator-Leveraging entrepreneurial agency? Journal of Business Venturing, 20(2), 265-290.

Boyack, K. W., \& Klavans, R. (2010). Co-citation analysis, bibliographic coupling, and direct citation: Which citation approach represents the research front most accurately? Journal of the American Society for Information Science and Technology, 61(12), 2389-2404.

Brooks, O. (1986). Economic development through entrepreneurship: Incubators and the incubation process. Economic Development Review, 4(2), 24-29.

Bruneel, J., Ratinho, T., Clarysse, B., \& Groen, A. (2012). The Evolution of Business Incubators: Comparing demand and supply of business incubation services across different incubator generations. Technovation, 32(2), 110-121. https://doi.org/10.1016/j.technovation.2011.11.003.

Campbell, C., \& Allen, D. N. (1987). The small business incubator industry: Micro-level economic development. Economic Development Quarterly, 1(2), 178-191.

Campbell, C., Kendrick, R. C., \& Samuelson, D. S. (1985). Stalking the latent entrepreneur: Business incubators and economic development. Economic Development Review, 3(2), 43-48. 
Carayannis, E. G., Popescu, D., Sipp, C., \& Stewart, M. (2006). Technological learning for entrepreneurial development (TL4ED) in the knowledge economy (KE): Case studies and lessons learned. Technovation, 26(4), 419-443. https://doi.org/10.1016/j.technovation.2005.04.003.

Carayannis, E. G., \& von Zedtwitz, M. (2005). Architecting gloCal (global-local), real-virtual incubator networks (G-RVINs) as catalysts and accelerators of entrepreneurship in transitioning and developing economies: Lessons learned and best practices from current development and business incubation practices. Technovation, 25(2), 95-110.

Chan, K., \& Lau, T. (2005). Assessing technology incubator programs in the science park: the good, the bad and the ugly. Technovation, 25(10), 1215-1228. https://doi.org/10.1016/j.technovation.2004.03.010.

Christensen, C. (1997). The innovator's dilemma: When new technologies cause great firms to fail. Boston, MA: Harvard Business School Print.

Clarysse, B., Wright, M., Lockett, A., Van de Velde, E., \& Vohora, A. (2005). Spinning out new ventures: A typology of incubation strategies from European research institutions. Journal of Business Venturing, 20(2), 183-216.

Cohen, S. (2013). What do accelerators do? Insights from incubators and angels. innovations, 8(3/4), 19-25.

Cohen, S., \& Hochberg, Y. V. (2014). Accelerating startups: The seed accelerator phenomenon. Available at SSRN 2418000. http://papers.ssrn.com/sol3/Papers.cfm?abstract_id=2418000. Accessed 9 January 2017.

Cohen, W. M., \& Levinthal, D. A. (1990). Absorptive capacity: A new perspective on learning and innovation. Administrative Science Quarterly, 35(1), 128-152.

Collinson, S., \& Gregson, G. (2003). Knowledge networks for new technology-based firms: An international comparison of local entrepreneurship promotion. $R \&$ D Management, 33(2), 189-208. https://doi.org/ 10.1111/1467-9310.00292.

Colombo, M., \& Delmastro, M. (2002). How effective are technology incubators? Evidence from Italy. Research Policy, 31(7), 1103-1122. https://doi.org/10.1016/S0048-7333(01)00178-0.

Cooper, A. C. (1985). The role of incubator organizations in the founding of growth-oriented firms. Journal of Business Venturing, 1(1), 75-86.

Dahlander, L., \& Gann, D. M. (2010). How open is open innovation? Research Policy, 39, 699-709. https:// doi.org/10.1016/j.respol.2010.01.013.

Etzkowitz, H. (2001). The second academic revolution and the rise of entrepreneurial science. IEEE Technology and Society Magazine, 20(2), 18-29. https://doi.org/10.1109/44.948843.

Etzkowitz, H., Mello, J. M. C., \& Almeida, M. (2005). Towards 'meta-innovation' in Brazil: The evolution of the incubator and the emergence of a triple helix". Research Policy, 34(4), 411-424.

European Commission (2002). Benchmarking of Business Incubators. Final Report for the EC's EnterpriseDirectorate-General.

Feeser, H. R., \& Willard, G. E. (1989). Incubators and performance: A comparison of highand low-growth high-tech firms. Journal of Business Venturing, 4(6), 429-442.

Fonseca, S. A., \& Chiappetta Jabbour, C. J. (2012). Assessment of business incubators' green performance: A framework and its application to Brazilian cases. Technovation, 32(2), 122-132. https://doi.org/10. 1016/j.technovation.2011.10.006.

Ford, S., Garnsey, E., \& Probert, D. (2010). Evolving corporate entrepreneurship strategy: Technology incubation at Philips. $R \& D$ Management, 40(1), 81-90.

Grimaldi, R., \& Grandi, A. (2005). Business incubators and new venture creation: an assessment of incubating models. Technovation, 25(2), 111-121. https://doi.org/10.1016/S0166-4972(03)00076-2.

Hackett, S. M., \& Dilts, D. M. (2004). A systematic review of business incubation research. Journal of Technology Transfer, 29, 55-82.

Hannan, M. T., \& Freeman, J. (1984). Structural inertia and organizational change. American sociological review, 49(2), 149-164.

Hansen, M. T., Chesbrough, H. W., Nohria, N., \& Sull, D. N. (2000). Networked incubators-Hothouses of the new economy. Harvard Business Review, 78(5), 74-84.

Hochberg, Y. V. (2016). Accelerating entrepreneurs and ecosystems: The seed accelerator model. Innovation Policy and the Economy, 16(1), 25-51.

Honig, B., \& Karlsson, T. (2010). Social capital and the modern incubator: A comparison of in-group and out-group social networks. Journal of Small Business \& Entrepreneurship, 23(sup1), 719-731.

Hughes, M., Ireland, R. D., \& Morgan, R. E. (2007). Stimulating dynamic value: Social capital and business incubation as a pathway to competitive success. Long Range Planning, 40(2), 154-177. https://doi.org/ 10.1016/j.lrp.2007.03.008.

Jenkins, D. R. (2001). Lockheed secret projects: Inside the Skunk Works. Zenith Imprint.

Kohler, T. (2016). Corporate accelerators: Building bridges between corporations and startups. Business Horizons, 59, 347-357. 
Kroll, H., \& Liefner, I. (2008). Spin-off enterprises as a means of technology commercialisation in a transforming economy-Evidence from three universities in China. Technovation, 28(5), 298-313. https://doi.org/10.1016/j.technovation.2007.05.002.

Kuratko, D. F., \& LaFollette, W. R. (1987). Small business incubators for local economic development. Economic Development Review, 5(2), 49.

Lasrado, V., Sivo, S., Ford, C., O’Neal, T., \& Garibay, I. (2016). Do graduated university incubator firms benefit from their relationship with university incubators? Journal of Technology Transfer, 41(2), 205-219.

Lewis, D. A. (2001). Does technology incubation work? A critical review. In Reviews of Economic Development Literature and Practice No. 11, 48 p.

Lindelof, P., \& Lofsten, H. (2003). Science park location and new technology-based firms in SwedenImplications for strategy and performance. Small Business Economics, 20(3), 245-258. https://doi.org/ 10.1023/A:1022861823493.

Lockett, A., Siegel, D., Wright, M., \& Ensley, M. D. (2005). The creation of spin-off firms at public research institutions: Managerial and policy implications. Research Policy, 34(7), 981-993. https://doi.org/10. 1016/J.RESPOL.2005.05.010.

Lofsten, H., \& Lindelof, P. (2001). Science parks in Sweden-Industrial renewal and development? $R \& D$ Management, 31(3), 309-322.

Lofsten, H., \& Lindelof, P. (2003). Determinants of entrepreneurial milieu: Science parks and business policy in growing firms. Technovation, 23(1), 51-64.

Lumpkin, J. R., \& Ireland, R. D. (1988). Screening practices of new business incubators: The evaluation of critical success factors. American Journal of Small Business, 12(4), 59-81.

Luria, D., \& Wiarda, E. (1996). Performance benchmarking and measuring program impacts on customers: Lessons from the Midwest Manufacturing Technology Center. Research Policy, 25(2), 233-246. https://doi.org/10.1016/0048-7333(95)00837-3.

Markley, D., \& McNamara, K. T. (1995). Economic and fiscal impacts of a business incubator. Economic Development Quarterly, 9(3), 273-278. https://doi.org/10.1177/089124249500900307.

Markman, G., Phan, P., Balkin, D., \& Gianiodis, P. (2005). Entrepreneurship and university-based technology transfer. Journal of Business Venturing, 20(2), 241-263. https://doi.org/10.1016/j.jbusvent. 2003.12.003.

Mas-Verdu, F., Ribeiro-Soriano, D., \& Roig-Tierno, N. (2015). Firm survival: The role of incubators and business characteristics. Journal of Business Reserach, 68(4), 793-796. https://doi.org/10.1016/j. jbusres.2014.11.030.

McAdam, M., Galbraith, B., McAdam, R., \& Humphreys, P. (2006). Business processes and networks in university incubators: A review and research agendas. Technology Analysis \& Strategic Management, $18(5), 451-472$.

Mcadam, M., \& Marlow, S. (2007). Building futures or stealing secrets? Entrepreneurial cooperation and conflict within business incubators. International Small Business Journal, 25(4), 361-382. https://doi. org/10.1177/0266242607078563.

McAdam, M., \& McAdam, R. (2008). High tech start-ups in University Science Park incubators: The relationship between the start-up's lifecycle progression and use of the incubator's resources. Technovation, 28(5), 277-290.

Mian, S. A. (1994). US-university-sponsored technology incubators: An overview of management, policies and performance. Technovation, 14(8), 515-528. https://doi.org/10.1016/0166-4972(94)90151-1.

Mian, S. A. (1996). Assessing value-added contributions of university technology business incubators to tenant firms. Research Policy, 25(3), 325-335. https://doi.org/10.1016/0048-7333(95)00828-4.

Mian, S. A. (1997). Assessing and managing the university technology business incubator: An integrative framework. Journal of Business Venturing, 12(4), 251-285. https://doi.org/10.1016/S08839026(96)00063-8.

Mian, S. A., Lamine, W., \& Fayolle, A. (2016). Technology business incubation: An overview of the state of knowledge. Technovation, 50-51(SI), 1-12. https://doi.org/10.1016/j.technovation.2016.02.005.

Patton, D., Warren, L., \& Bream, D. (2009). Elements that underpin high-tech business incubation processes. Journal of Technology Transfer, 34(6), 621-636. https://doi.org/10.1007/s10961-009-9105-7.

Peña, I. (2004). Business incubation centers and new firm growth in the Basque Country. Small Business Economics, 22(3-4), 223-236. https://doi.org/10.1023/B:SBEJ.0000022221.03667.82.

Perez, M. P., \& Sanchez, A. M. (2003). The development of university spin-offs: Early dynamics of technology transfer and networking. Technovation, 23(10), 823-831.

Peters, L., Rice, M., \& Sundararajan, M. (2004). The role of incubators in the entrepreneurial process. The Journal of Technology Transfer, 29(1), 83-91. 
Phan, P. H., Siegel, D. S., \& Wright, M. (2005). Science parks and incubators: Observations, synthesis and future research. Journal of Business Venturing, 20, 165-182.

Plosila, W. H., \& Allen, D. N. (1985). Small business incubators and public policy: Implications for state and local development strategies. Policy Studies Journal. https://doi.org/10.1111/j.1541-0072.1985. tb01612.x.

Ratinho, T., \& Henriques, E. (2010). The role of science parks and business incubators in converging countries: Evidence from Portugal. Technovation, 30(4), 278-290. https://doi.org/10.1016/j. technovation.2009.09.002.

Rice, M. P. (2002). Co-production of business assistance in business incubators: An exploratory study. Journal of Business Venturing, 17, 163-187.

Roig-Tierno, N., Alcazar, J., \& Ribeiro-Navarrete, S. (2015). Use of infrastructures to support innovative entrepreneurship and business growth. Journal of Business Reserach, 68(11), 2290-2294. https://doi. org/10.1016/j.jbusres.2015.06.013.

Rothaermel, F., \& Thursby, M. (2005). University-incubator firm knowledge flows: Assessing their impact on incubator firm performance. Research Policy, 34(3), 305-320. https://doi.org/10.1016/j.respol.2004. 11.006.

Rothschild, L., \& Darr, A. (2005). Technological incubators and the social construction of innovation networks: An Israeli case study. Technovation, 25(1), 59-67. https://doi.org/10.1016/S01664972(03)00064-6.

Rubin, T. H., Aas, T. H., \& Stead, A. (2015). Knowledge flow in technological business incubators: evidence from Australia and Israel. Technovation, 41-42, 11-24. https://doi.org/10.1016/j. technovation.2015.03.002.

Schildt, H. A., Zahra, S. A., \& Sillanpää, A. (2006). Scholarly communities in entrepreneurship research: A co-citation analysis. Entrepreneurship Theory and Practice, 30(3), 399-415.

Schwartz, M. (2009). Beyond incubation: An analysis of firm survival and exit dynamics in the postgraduation period. Journal of Technology Transfer, 34(4), 403-421. https://doi.org/10.1007/s10961008-9095-x.

Schwartz, M. (2013). A control group study of incubators' impact to promote firm survival. Journal of Technology Transfer, 38(3), 302-331. https://doi.org/10.1007/s10961-012-9254-y.

Schwartz, M., \& Hornych, C. (2008). Specialization as strategy for business incubators: An assessment of the Central German Multimedia Center. Technovation, 28(7), 436-449. https://doi.org/10.1016/j. technovation.2008.02.003.

Scillitoe, J. L., \& Chakrabarti, A. K. (2010). The role of incubator interactions in assisting new ventures. Technovation, 30(3), 155-167. https://doi.org/10.1016/j.technovation.2009.12.002.

Sherman, H. D. (1999). Assessing the intervention effectiveness of business incubation programs on new business start-ups. Journal of Developmental Entrepreneurship, 4(2), 117.

Sherman, H., \& Chappell, D. (1998). Methodological challenges in evaluating business incubator outcomes. Economic Development Quarterly, 12(4), 313-321. https://doi.org/10.1177/089124249801200403.

Smilor, R. W., \& Gill, M. D. (1986). The New Business Incubator: linking talent, technology, capital, and know-how. Lexington, MA: Lexington Books.

Spigel, B. (2015). The relational organization of entrepreneurial ecosystems. Entrepreneurship Theory and Practice. http://onlinelibrary.wiley.com/doi/10.1111/etap.12167/pdf. Accessed 19 October 2016.

Stokan, E., Thompson, L., \& Mahu, R. J. (2015). Testing the differential effect of business incubators on firm growth. Economic Development Quarterly, 29(4), 317-327. https://doi.org/10.1177/ 0891242415597065.

Tötterman, H., \& Sten, J. (2005). Start-ups-Business incubation and social capital. International Small Business Journal, 23(5), 487-511. https://doi.org/10.1177/0266242605055909.

Tsai, F. S., Hsieh, L. H., Fang, S. C., \& Lin, J. L. (2009). The co-evolution of business incubation and national innovation systems in Taiwan. Technological Forecasting and Social Change, 76(5), 629-643. https://doi.org/10.1016/j.techfore.2008.08.009.

Tushman, M. L., \& O'Reilly, C. A. (1996). The ambidextrous organizations: Managing evolutionary and revolutionary change. California Management Review, 38(4), 8-30.

Udell, G. (1990). Are business incubators really creating new jobs by creating new businesses and new products. Journal of Product Innovation Management, 7(2), 108-122. https://doi.org/10.1016/07376782(90)90053-H.

van Weele, M., van Rijnsoever, F. J., \& Nauta, F. (2016). You can't always get what you want: How entrepreneur's perceived resource needs affect the incubator's assertiveness. Technovation, 59, 18-33.

Vanderstraeten, J., \& Matthyssens, P. (2012). Service-based differentiation strategies for business incubators: Exploring external and internal alignment. Technovation, 32(12), 656-670. https://doi.org/10. 1016/j.technovation.2012.09.002. 
von Zedtwitz, M. (2003). Classification and management of incubators: Aligning strategic objectives and competitive scope for new business facilitation. International Journal Entrepreneurship and Innovation Management, 3, 176-196.

von Zedtwitz, M., \& Grimaldi, R. (2006). Are service profiles incubator-specific? Results from an empirical investigation in Italy. Journal of Technology Transfer, 31(4), 459-468.

Weiblen, T., \& Chesbrough, H. W. (2015). Engaging with startups to enhance corporate innovation. California Management Review, 57(2), 66-90.

Weinberg, M. L., Allen, D. N., \& Schermerhorn, J. R., Jr. (1991). Interorganizational challenges in the design and management of business incubators. Review of Policy Research, 10(2-3), 149-160.

Wolcott, R. C., \& Lippitz, M. J. (2007). The four models of corporate entrepreneurship. MIT Sloan Management Review, 49(1), 75. 